\title{
Risk Management Practices in Small and Medium Enterprises: Evidence from Romania
}

\author{
Adina-Liliana PRIOTEASA ${ }^{1}$ \\ Nicoleta CHICU2 \\ Alina-Andreea ȘTEFĂNESCU (MARIN) ${ }^{3}$ \\ Alexandru Mihai BUGHEANU4 \\ Ruxandra DINULESCU5
}

\begin{abstract}
Small and medium enterprises (SMEs) face various risks and their survival is more easily threatened due to the lower volume of resources - both financial and non-financial. Integrating risk management into SMEs produces the same benefits as for a large enterprise, allowing the small business owner to act strategically, anticipate risk events and allocate resources to control risk events. This study aims to determine, on the one hand, whether the organizational factors of Romanian SMEs influence the extent to which risk management is integrated into the current activities of SMEs, and on the other hand if there is a significant relationship between the extent to which SMEs use risk management practices and the extent to which risk management is integrated into current activities. The data were collected from 164 representatives of Romanian SMEs by applying a questionnaire and analyzed using Oneway ANOVA and Multiple Linear Regression at a significance level of 0.01. The results show that organizational differences affect the extent to which risk management is integrated into the current activities of SMEs. The results also show that there is a positive and significant relationship between the extent to which Romanian SMEs apply risk identification techniques, risk assessment analyses and risk treatment methods and the extent to which risk management is integrated into current activities.
\end{abstract}

KEYWORDS: organizational factors, risk management, risk management practices, Romania, SMEs.

JEL CLASSIFICATION: $C 12, G 32, L 26$

\section{INTRODUCTION}

Small and medium-sized enterprises play an important role in the global economy, they promote inclusive and sustainable economic growth, ensure decent jobs, encourage sustainable industrialization and innovation and reduce income inequalities. (OECD, 2017, p. 5). For example, in Europe, a recent European Commission study indicates that in 2017, the contribution of SMEs to value added was $56.8 \%, 13.6 \%$ more than that of large enterprises

\footnotetext{
${ }^{1}$ Bucharest University of Economic Studies, Bucharest, Romania, prioteasaadina@gmail.com. Corresponding author

${ }^{2}$ Bucharest University of Economic Studies, Bucharest, Romania, chicu_nicoleta@yahoo.com

${ }^{3}$ Bucharest University of Economic Studies, Bucharest, Romania, alina.marin@man.ase.ro

${ }^{4}$ Bucharest University of Economic Studies, Bucharest, Romania, mihai.bugheanu@man.ase.ro

${ }^{5}$ Bucharest University of Economic Studies, Bucharest, Romania, ruxandra.dinulescu@man.ase.ro
} 
(43.2\%), and $66.4 \%$ in employment, with $33.2 \%$ more than large enterprises (33.6\%) (European Commission, 2018, p. 14).

Compared to large companies, the main strengths of SMEs lie in a simple organization characterized by less formalized relationships and much reduced bureaucratic practices, in a rapid decision-making process given the low volume of operational and management expenditure, and in a high capacity to adapt to changes in the market (Yilmaz, 2004 citat în Keskin, et al., 2010, p. 185).

At the same time, SMEs face a wide and complex range of challenges, such as high vulnerability to changes in the external environment, barriers in the supply of global resources, lack of managerial capabilities, lack of funding, difficulty in accessing technological resources and heavy regulatory burden (Muhammad, Char, Yasoa, \& Hassan, 2010, p. 68). This indicates that SMEs face various risks and that their survival is more easily threatened due to the lower volume of resources - both financial and non-financial (Falkner \& Hiebl, 2015, p. 123).

Lack of risk management or defective risk management may directly affect day-to-day operations, reduce revenue or increase spending, and even lead to huge losses, seriously threatening the survival of SMEs (CPA Australia, 2009, p. 2).

Integrating risk management into SMEs produces the same benefits as for a large enterprise, allowing the small business owner to act strategically, anticipate risk events and allocate resources to control risk events. These offer the possibility of a faster recovery in the event of a risk event and a lower overall impact.

This study aims to determine, on the one hand, whether the organizational factors of Romanian SMEs influence the extent to which risk management is integrated into the current activities of SMEs, and on the other hand if there is a significant relationship between the extent to which SMEs use risk management practices and the extent to which risk management is integrated into current activities.

This paper is organized as follows. The second section analyzes the literature on risks and risk management in SMEs. The next part presents a brief introduction to the methodology used in the study. The fourth section contains the debate on empirical findings. The conclusion together with the managerial implications are presented with the final section.

\section{LITERATURE REVIEW}

\subsection{Risk terminology in SMEs}

The literature shows that there is no universally accepted definition of risk, but there are a number of different ways of understanding it (Aven, 2012, p. 33). This may be due to different appreciations that tries to capture different phenomena bearing the same name "risk" (Brustbauer, 2016, p. 71).

In the last two decades, many studies, standards and legislation have attempted to define risk. In most of these, the negative sense of risk is treated (Broadleaf Capital International, 2012, p. 1). The traditional definition of risk focuses on two variables: the frequency (probability) of occurrence of the event and the consequences (magnitude) that the event generates (Verbano \& Venturini, 2013, p. 187).

Hillson (2002, p. 235) addresses risk as an "umbrella" notion, encompassing both the term opportunity (positive effect) and the term threat (negative effect). The researchers conduct a comparative study of standards from the perspective of defining risk, arguing that the definitions of risk present in the literature can fall into three categories, namely: negative definitions, neutral definitions and comprehensive definitions (Raz \& Hillson, 2005, p. 64). 
Atât Standards Australia/Standards New Zeeland (2004), Project Management Institute (2008), cât și ISO 31000:2009 (2009), characterizes the risk not only that the probability of something happening but also that it has an impact on the objectives. Within them, the impact is not limited as having only a negative effect but associates the risk with possible positive or negative consequences.

Despite these discussions, a comprehensive and accepted definition of risk is provided by ISO Guide 73: 2009, in which risk is the "risk effect of uncertainty on objectives". It is also stated that the effect can be positive, negative or a deviation from expectations, and the risk is often described by an event, a change in circumstances or a consequence (AIRMIC, ALARM, \& IRM, 2010, p. 4).

Risk is a current and sensitive concern for the entire business environment, but especially for small and medium-sized enterprises, where it is somewhat difficult to characterize (Alquier \& Tignol, 2006, p. 273). Its significance for small and medium-sized enterprises is much higher due to the fact that their resources are limited (Popa, Miricescu, \& Faloba, 2015, p. 2).

The terminology regarding risks vary from one organization to another, in which staff tend to use different expressions to describe the same risk, or use the same terms for totally different risks (Kelliher, Wilmot, Vij, \& Klumpes, 2011, p. 1). Risk classification systems have a strong significance for organizations because they have the role of identifying accumulations of similar risks (AIRMIC, ALARM, \& IRM, 2010, p. 5).

A risk classification commonly used, which concerns the organization as a whole, includes: strategic risks, operational risks, financial risks, risks related to hazard (IMA, 2011, p. 5). Regarding small and medium enterprises, Falkner \& Hiebl (2015, p. 125) identify the most common types of risks that influence their activity. Figure 1 shows the specific risks for small and medium-sized enterprises.

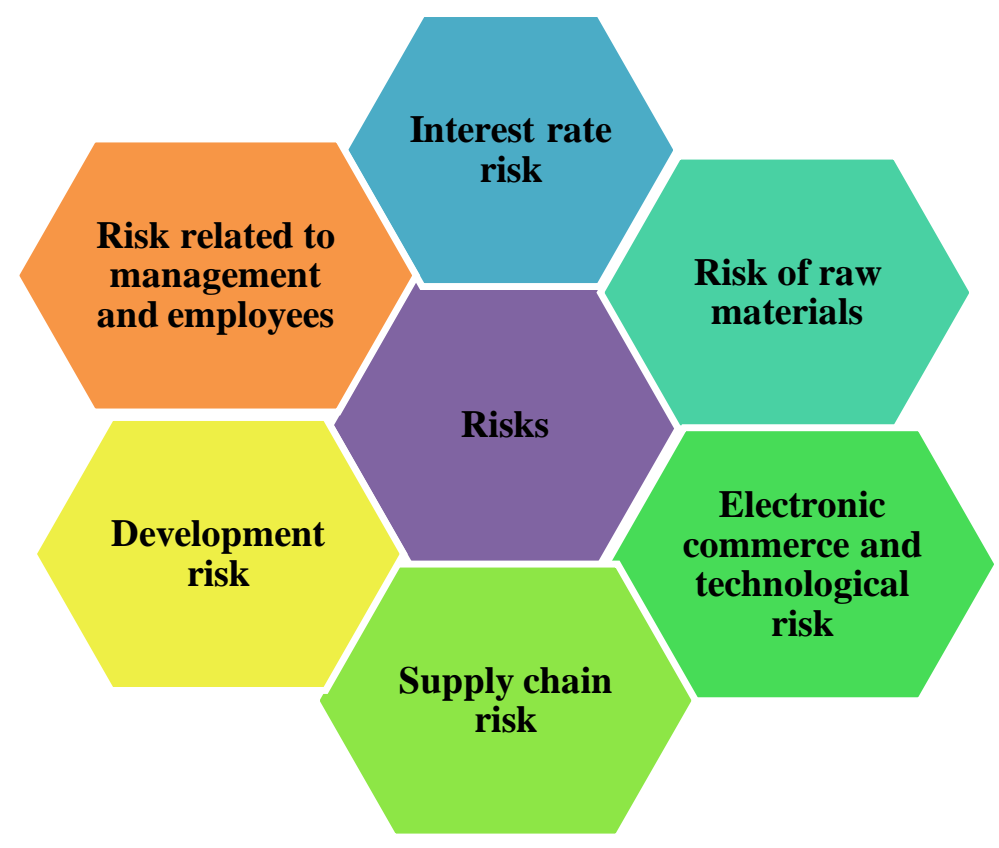

Figure 1. The risks specific to SMEs

Source: Adapted from Falkner \& Hiebl (2015)

\subsection{Risk management}

Closely related to the evolution of the concept of risk is that of risk management. It crossed different stages of development and has gradually evolved from an "in silo" towards an integrated. Unpredictability is the only constant of events that were the foundation of the 
development of the risk management industry before 1970 (Global Association of Risk Professionals, 2007, p. 6). The field of risk management, before 1970, was characterized in the business environment by the fact that organizations paid more attention to the risks that could affect their activity, and the way in which they managed such situations was represented by the acquisition of insurances (Buehler, Freeman, \& Hulme, 2008).

The concept of risk management at the enterprise level or integrated risk management appeared in the 1990s, until then organizations used different parts of risk management. The common practices used consist in identifying and prioritizing risks either by forecasting or following the occurrence of events, and in treating them by purchasing insurance (The Institutes, n.d, p. 3). In recent decades, risk management has reached a new level of importance in both business and academia and research, as a result of continuous changes in the economic environment. Globally, there is a trend of proliferation of risk management at the same time with an increase in awareness of its contribution to achieving organizational goals and a focus on increasingly complex risks (Frigo \& Anderson, 2011, p. 81).

The integrated approach to risk management transforms generic risk management into a proactive, continuous, value-based activity with a broad focus and a process orientation, these contributions redefine the value proposition that risk management has for a business (Louw \& Com, 2007, p. 16). In the literature, this discipline is designated by the following names: total risk management (TRM), integrated risk management (IRM), holistic risk management (HRM) or enterprise risk management (ERM). ERM is a structured and disciplined approach to help management understand and manage uncertainties and encompasses all business risks using an integrated and holistic approach (Sobel \& Reding, 2004, p. 29).

Regardless of the terms used, risk management is related to how to organize and achieve the identification, analysis and control of threats and opportunities that organizations face in achieving their objectives (Djapic, Lukic, \& Popovic, 2013, p. 723).

\subsection{Risk management in SMEs}

Small and medium-sized enterprises (SMEs) are recognized worldwide as the engines of socio-economic development due to their important role in GDP growth, new job creation and entrepreneurship (Karadag, 2016, p. 22). The role of SMEs in Romania is no exception, according to data presented by the European Commission, small businesses have contributed over $60 \%$ of total employment and $50 \%$ of total value added (European Commission, 2018).

According to John W. Snow, Secretary f the United States of America Department of the Treasury, small and medium-sized enterprises "They are a category full of courage ... no one works like them and no one takes greater risks" (Savlovschi \& Robu, 2011, p. 279). Risk management is a challenge for SMEs, often the lack of financial, human resources, experience and specific knowledge prevents them from developing a structured approach to risk management (Henschel, 2008, p. 15). In addition, issues such as inadequate infrastructure, limited managerial and technical expertise, weak information networks, inability to recognize relevant data in risk management, but also low investment in research and development makes it difficult for SMEs to take a positive approach to risk management (Janney \& Dess, 2006, p. 394).

The owner-manager has a significant influence on the implementation or application of risk management practices in SMEs, thus their lack of knowledge or expertise in identifying, analyzing and treating risks can pose a real threat to the sustainability of SMEs (Watt, 2007, p. 32). Therefore, the need to develop the knowledge and awareness of owner-managers regarding risk management through appropriate training is emphasized. (Jayathilake, 2012, p. 233), but also the use of existing and extensive knowledge of owner-managers related to the 
company's activity (marketing, production, finance, human resources) in risk management (Nieuwenhuizen, 2007, p. 2).

The existence of these challenges in the implementation of risk management in SMEs is possible in the context of treating risk management as a recent, sensitive and even inadequately defined topic despite the economic and social importance of SMEs (Alquier \& Tignol, 2006, p. 273; Crovini, 2019, p. 56). Another reason is that so far no standard or framework has been issued setting out the rules for the application of risk management in SMEs or that the existing standards and frameworks do not contain recommendations for this type of enterprise either (Rostami, Sommerville, Wong, \& Lee, 2015, p. 91).

In a recent study, about two thirds of Romanian SMEs stated that they manage risks and the rest were undecided in confirming or denying the existence of the application of risk management practices. Despite the overwhelming percentage of SMEs that have reported the use of risk management techniques and tools, in many of them there is no formalization, preferring to manage risks empirically, use their own methodologies or combine practices from different standards and / or methodologies. The indecision of Romanian SMEs in confirming the use of risk management techniques and tools and empirical risk management are clear signs of an immature risk management (Prioteasa \& Ștefan, 2019, p. 8679).

\section{RESEARCH METHODOLOGY}

The main objective of this study is to determine, on the one hand, whether the organizational factors of Romanian SMEs such as size, age on the market and the level at which they operate influence the extent to which risk management is integrated into the current activities of SMEs, and, on the other hand, whether the extent to which SMEs use risk management practices, such as risk identification techniques, risk assessment analyzes and risk treatment methods, and the degree of integration of risk management into current activities is a significant relationship.

To meet this objective, a questionnaire was developed. The survey was administered using an online questionnaire using the Google Forms platform. The research objectives were presented on the introduction page, and the following four sections covered closed questions on 4 main topics: (i) integrating risk management into current activities; (ii) the use of risk identification techniques, (iii) the use of risk assessment analyzes; (iv) the use of risk treatment methods. The final section (section v) was dedicated to collecting demographic data about participants and their organizations using closed-ended questions, with the possibility of choosing a single answer.

The first four parts of the questionnaire used interval rating scale measurement with five-point Likert-Scale. Participants were asked to choose from a five-point Likert scale, ranging mainly from "not at all" (coded as "1") to "very much" (coded as "5") for the first four topics.

Given the debates on the legitimacy of treating the Likert scale as interval data and their use in statistical procedures such as Linear Regression, ANOVA or Factor Analysis it is necessary to mention references that support this idea. Thus, Norman (2010, p. 631) states that parametric statistics can be used with Likert data, with small sample sizes, with unequal variations, and with non-normal distributions, without fear of reaching the wrong conclusion. Also, Grace-Martin (2008) suggests that when using Likert data in a parametric procedure is necessary to achieve strong results before making statements. It is recommended to use a stricter significance level of 0.01 or 0.005 instead of 0.05 . We considered a significance level of $1 \%$ in testing the hypotheses.

In this study, the following hypotheses will be tested:

H1: There is a significant effect of the size of Romanian SMEs on the extent to which risk management is integrated into current activities. 
H2: There is a significant effect of the market presence of Romanian SMEs on the extent to which risk management is integrated into current activities.

H3: There is a significant effect of the level at which Romanian SMEs carry out economic activities on the extent to which risk management is integrated into current activities.

H4: There is a significant relationship between the extent to which risk identification techniques are used and the extent to which risk management is integrated into the current activities of Romanian SMEs.

H5: There is a significant relationship between the extent to which risk assessment analysis are used and the extent to which risk management is integrated into the current activities of Romanian SMEs.

H6: There is a significant relationship between the extent to which risk treatment methods are used and the extent to which risk management is integrated into the current activities of Romanian SMEs.

For each hypothesis was defined the null hypothesis H0: The analysed variables are statisticaly independent (there is no association between the analysed variables) and the alternative hypothesis Ha: There is an association between the analysed variables.

In order to test the established hypotheses, the inferential analyzes represented by One-way ANOVA and Multiple Linear Regression at the level of statistical significance of $p<0.01$ will be used.

\section{RESULTS}

The descriptive statistical results show that the 164 Romanian organizations that participated in the survey belong to the category of micro-enterprises $(33.5 \%)$, small enterprises $(31.1 \%)$, and medium-sized enterprises $(35.4 \%)$, are present on the market for less than 1 year $(9.1 \%)$, $1-5$ years $(18.9 \%), 5-10$ years $(22.6 \%), 10-25$ years $(31.1 \%)$, over 25 years $(18.3 \%)$, carrying out activity at local (31.7\%), regional (28\%), national (26.8\%) and global (13.4\%) level. Central tendency and dispersion measurements were calculated to summarize the data and to understand the variability of scores for the size of SMEs, the market presence of SMEs and the level at which small companies operate. The results of these analyzes are as follows: $\mathrm{N}=$ $164 ; \mathrm{x}^{-}=2.02,3.30,2.22$; S.D. $=0.832,1.230,1.039$. Also, the risk management practices regarding the use of risk treatment methods have a high level of importance $\left(\mathrm{x}^{-}=3.1\right.$; $\mathrm{SD}=$ $1.193)$, the application of risk assessment analyzes have a moderate level of importance $\left(\mathrm{x}^{-}=\right.$ 2.82; $\mathrm{SD}=1.437)$, and the use of risk identification techniques a low level $\left(\mathrm{x}^{-}=2.79 ; \mathrm{SD}=\right.$ 1.352). The integration of risk management in the current activities of Romanian SMEs has a high level of impotence ( $\mathrm{x}^{-}=3.38$; S.D. $\left.=1.205\right)$.

One-way ANOVA (F test) is performed to determine the effect of the organizational size, the market presence of the company and the level at which it conducts its business on the integration of risk management in current activities. There is a significant effect of organizational size, seniority on the market and the level at which business is conducted on the extent to which risk management is integrated into current activities. Table 1 shows the differences between organizational factors (organizational size, age on the market and the level at which economic activity takes place) that affect the extent to which risk management is integrated into the current activities of Romanian SMEs. 
Table 1. Differences in organisational factors influencing integration of risk management in current activities

\begin{tabular}{|c|c|c|c|}
\hline & $\begin{array}{c}\text { The size of } \\
\text { Romanian SMEs }\end{array}$ & $\begin{array}{c}\text { The market presence } \\
\text { of Romanian SMEs }\end{array}$ & $\begin{array}{c}\text { The level at which } \\
\text { Romanian SMEs } \\
\text { operate }\end{array}$ \\
\hline $\begin{array}{c}\text { Integration of risk } \\
\text { management in } \\
\text { current activities }\end{array}$ & $\begin{array}{c}\mathrm{F}(2,161)=28.606, \\
p=0.001\end{array}$ & $\begin{array}{c}\mathrm{F}(4,159)=5.52, \\
p=0.001\end{array}$ & $\begin{array}{c}\mathrm{F}(3,160)=7.655, \\
p=0.001\end{array}$ \\
\hline
\end{tabular}

Source: Own calculations

There is a significant effect of the organizational dimension on the integration of risk management in current activities in SMEs, at the level of $p<0.01$, for the three conditions $\mathrm{F}(2,161)=28.606, p=0.001$. Post-hoc comparisons use the Fisher's Least Significant Difference (LSD) test, the results of this test indicate that the average score for microenterprises ( $\leq 9$ employees; $\leq 2$ mil. Euro turnover) $-\bar{x}=2.98$, S.D. $=1.114$ is significantly different from medium-sized enterprises $(\leq 249$ employees; $\leq 50$ mil. Euro turnover $)-\bar{x}=$ 4.21, S.D. $=0.932$. However, there are no significant differences between small ( $\leq 49$ employees; $\leq 10$ mil. Euro turnover $)-\bar{x}=2.86$, S.D. $=1.077$ and micro-enterprises, but the differences materialize in the comparison between small and medium enterprises. Analyzed together, these results suggest that Romanian medium-sized enterprises have a high influence on the integration of risk management practices in current activities.

Also, the extent to which risk management is integrated into the current activities of Romanian SMEs is significantly influenced by the market presence, at the level of $p<0.01$, for the five conditions $F(4,159)=5.52, p=0.001$. Post-hoc comparisons using the LSD test indicate that the average score for SMEs with a market presence of less than 1 year $(\bar{x}=2.33$, S.D. = 1.345) it is significantly different from SMEs with a seniority of 1-5 years $(\bar{x}=3.16$, S.D. $=1.098), 5-10$ years $(\bar{x}=3.84$, S.D. $=1.323), 10-25$ years $(\bar{x}=3.59$, S.D. $=1.004)$ and over 25 years $(\bar{x}=3.20$, S.D. $=1.064)$. Moderate differences occur between SMEs with a seniority of 5-10 years $(\bar{x}=3.84$, S.D. $=1.323)$ and those with a market presence of $1-5$ years $(\bar{x}=3.16$, S.D. $=1.098)$ and over 25 years $(\bar{x}=3.20$, S.D. $=1.064)$. These results indicate that SMEs with an average market presence (5-10 years) influence the extent to which risk management is integrated into current activities.

The level at which SMEs operate has a significant impact on the degree to which risk management is incorporated into current activities, at the level of $\mathrm{p}<0.01$, for the four conditions $\mathrm{F}(3,160)=7.655, p=0.001)$. Post-hoc comparisons using the LSD test indicate that the average score of SMEs operating at local $(\bar{x}=3.19$, S.D. $=0.908)$, regional $(\bar{x}=3.17$, S.D.= 1.419), and national level $(\bar{x}=3.27$, S.D. $=1.208)$ is significantly different from SMEs operating globally $(\bar{x}=4.45$, S.D. $=0.739)$. However, there is no significant difference between SMEs operating locally, regionally and nationally, leading to the conclusion that SMEs operating globally significantly impact the extent to which risk management practices are included in current activities.

Before analyzing the regression model, the multicollinearity test was performed, given that multicollinearity can affect the parameters of the regression model. Adeyemi \& Fagbemi (2010, p. 174) indicates that a tolerance value of less than 0.1 reveals a serious multicollinearity problem between the independent variables. However, given that all values are greater than 0.10 , there is no multi-collinearity problem between the independent variables of this study. Also, Myers (1990, p. 369) suggests that a value of variance inflation factor (VIF) greater than 10, requests concern, however, for this study, VIF values are less than 10. 
In Table 2, the results of the linear regression show that the correlation between the dependent variable, which is represented by the degree of integration of risk management in current activities and the predictors represented by the extent to which risk identification techniques are used ( 9 variables - interviews, questionnaires, brainstorming, discussions with colleagues, workshops, checklists, comparisons with other organizations, product / process diagrams, benchmarking, external consultants, scenario method) has a high value (0.665) and in the same direction.

Also, from the results of the regression analysis for SMEs selected, as described in Table 2, show that $\mathrm{R}$ Square, which is often referred to as the coefficient of determination of the variables has a value of 0.443 . $\mathrm{R}$ Square indicates that the model is able to explain approximately $44.3 \%$ of the variability of integrating risk management into the current activities of SMEs in Romania. This means that approximately $55.7 \%$ of the variation in risk management integration, the current activities of the sampled SMEs are accounted for by other factors that are not included in the model. This result is corroborated by the Adjusted $\mathrm{R}$ Square of approximately 0.403 , which is essentially the proportion of total variation explained by the model.

Table 2. Multiple correlation between risk identification techniques and dependent variable

\begin{tabular}{|c|c|c|c|c|c|c|c|}
\hline \multirow[b]{2}{*}{ Model } & \multirow[b]{2}{*}{$\mathbf{R}$} & \multirow{2}{*}{$\begin{array}{c}\text { R } \\
\text { Squar } \\
\mathbf{e}\end{array}$} & \multirow{2}{*}{$\begin{array}{l}\text { Adjuste } \\
\text { d R } \\
\text { Square }\end{array}$} & \multirow{2}{*}{$\begin{array}{c}\text { Std. } \\
\text { Error } \\
\text { of the } \\
\text { Estimate }\end{array}$} & \multicolumn{3}{|c|}{ Change Statistics } \\
\hline & & & & & $\begin{array}{c}\text { R Square } \\
\text { Change }\end{array}$ & $\begin{array}{c}\text { F } \\
\text { Change }\end{array}$ & $\begin{array}{c}\text { Sig. F } \\
\text { Change }\end{array}$ \\
\hline $\begin{array}{c}\text { Risk } \\
\text { identification } \\
\text { techniques }\end{array}$ & 0.665 & 0.443 & 0.403 & 0.931 & 0.443 & 10.983 & 0.000 \\
\hline
\end{tabular}

Source: Own calculations

Similarly, the results of the F-Statistics test, as reflected in Table 2, show a $p$ value of less than 0.01 ; this clearly suggests that simultaneously the explanatory variables (interviews, questionnaires, brainstorming, discussions with colleagues, workshops, checklists, comparisons with other organizations, product / process diagrams, benchmarking, external consultants, scenario method) are significantly associated with the dependent variable, the integration of risk management in current activities.

In Table 3, the results of the linear regression analysis show that the risk identification techniques that influence the extent to which risk management is incorporated into current activities, at the level of statistical significance of 0.01 , are represented by questionnaires ( $t$ statistics $=-2.965$; $\mathrm{p}$-value $<0.004$ ).

The questionnaires have the highest beta coefficient - 0.353, which means that their use in risk identification has the greatest influence on predicting the degree of integration of risk management in current activities of Romanian SMEs. The association between the extent to which questionnaires are used in identifying risks and the extent to which risk management is taken into account in carrying out current activities is significant and negative, which means that the higher the extent to which questionnaires are used in the risk identification process, the lower the degree to which risk management is integrated, and conversely, the lower the extent to which questionnaires are used in the risk identification process, the higher the extent to which risk management is integrated into current activities. 
Table 3. Multiple regression between risk identification techniques and dependent variable

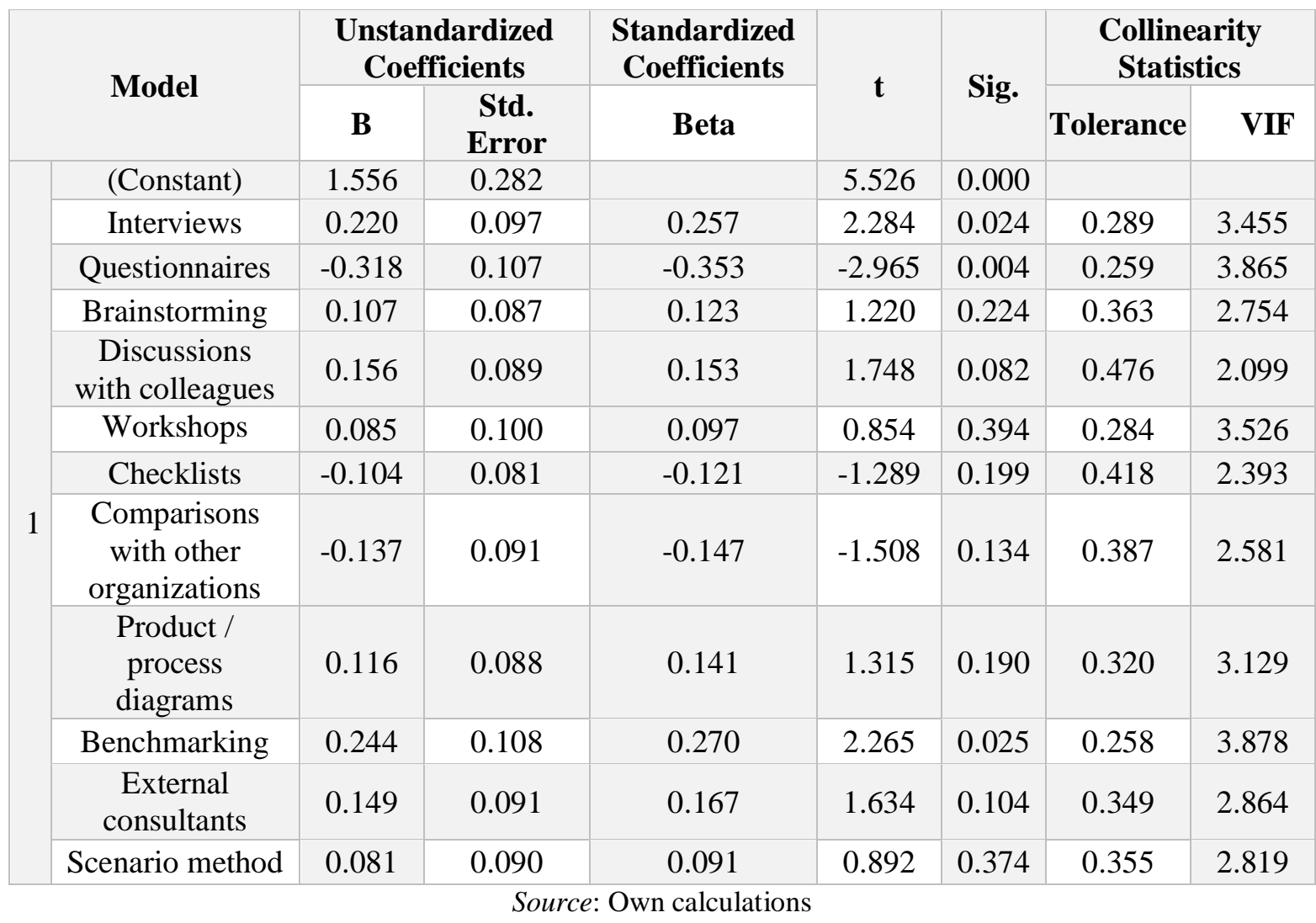

The results of the linear regression, presented in Table 4, show that the correlation between the dependent variable, which is represented by the extent to which risk management is integrated in the current operations of Romanian SMEs and the predictors represented by the extent to which risk assessment analyses are used (2 variables - qualitative analysis, quantitative analysis) has a high value (0.603) and in the same direction.

Also, the results of the regression analysis for the selected SMEs, described in Table 4, show that R Square, which is often called the coefficient of determination of the variables, has a value of 0.364 . R-Square indicates that the model is able to explain approximately $36.4 \%$ of the variability of risk management integration in the current activities of SMEs in Romania. This means that approximately $63.6 \%$ of the variations in the integration of risk management in the current activities of the sampled SMEs are accounted for by other factors that are not included in the model. This result is confirmed by Adjusted R Square of approximately 0.356, which is essentially the proportion of total variation explained by the model.

Table 4. Multiple correlation between risk assessment analyses and dependent variable

\begin{tabular}{|c|c|c|c|c|c|c|c|}
\hline Model & R & $\begin{array}{c}\text { R } \\
\text { Square }\end{array}$ & $\begin{array}{c}\text { Adjusted } \\
\text { R Square }\end{array}$ & $\begin{array}{c}\text { Std. } \\
\text { Error } \\
\text { of the } \\
\text { Estimate }\end{array}$ & $\begin{array}{c}\text { Change Statistics } \\
\text { Square } \\
\text { Change }\end{array}$ & $\begin{array}{c}\text { F } \\
\text { Change }\end{array}$ & $\begin{array}{c}\text { Sig. F } \\
\text { Change }\end{array}$ \\
\hline $\begin{array}{c}\text { Risk assessment } \\
\text { analyses }\end{array}$ & 0.603 & 0.364 & 0.356 & 0.967 & 0.364 & 46.109 & 0.001 \\
\hline
\end{tabular}

Source: Own calculations 
The results of the F-Statistics test, as shown in Table 4 , have a $p$ value of less than 0.01 , this indicates precisely that simultaneously the explanatory variables (qualitative analysis and quantitative analysis) are significantly associated with the dependent variable, risk management integration in the current activities of Romanian SMEs.

In Table 5, the results of the linear regression analysis show that of the two independent variables only the quantitative risk assessment analysis (t-statistics=6.112; p-value $<0.001$ influences the extent to which risk management is included incorporated in current activities at the level of statistical significance of 0.01 .

Quantitative analysis has the highest beta coefficient (0.661), which means that the use of quantitative analysis in risk assessment has the greatest influence on the extent to which risk management is integrated into current activities of Romanian SMEs. The significant and positive association between the use of quantitative risk assessment analysis and the integration of risk management into current activities means that the greater the extent to which quantitative analyzes are used, the greater the extent to which risk management is integrated.

Table 5. Multiple regression between risk assessment analyses and dependent variable

\begin{tabular}{|c|c|c|c|c|c|c|c|c|}
\hline & \multirow{2}{*}{ Model } & \multicolumn{2}{|c|}{$\begin{array}{c}\text { Unstandardized } \\
\text { Coefficients }\end{array}$} & \multirow{2}{*}{$\begin{array}{c}\begin{array}{c}\text { Standardized } \\
\text { Coefficients }\end{array} \\
\text { Beta }\end{array}$} & \multirow{2}{*}{$\mathbf{t}$} & \multirow{2}{*}{ Sig. } & \multicolumn{2}{|c|}{$\begin{array}{c}\text { Collinearity } \\
\text { Statistics }\end{array}$} \\
\hline & & B & $\begin{array}{l}\text { Std. } \\
\text { Error }\end{array}$ & & & & Tolerance & VIF \\
\hline \multirow{3}{*}{1} & (Constant) & 2.080 & 0.175 & & 11.870 & 0.000 & & \\
\hline & $\begin{array}{l}\text { Qualitative } \\
\text { analysis }\end{array}$ & -0.063 & 0.095 & -0.072 & -0.668 & 0.505 & 0.339 & 2.949 \\
\hline & $\begin{array}{l}\text { Quantitative } \\
\text { analysis }\end{array}$ & 0.529 & 0.086 & 0.661 & 6.122 & 0.000 & 0.339 & 2.949 \\
\hline
\end{tabular}

The results of the linear regression, presented in Table 6, demonstrate that the correlation between the dependent variable, which is represented by measures of risk management integration in current activities and the predictors represented by the extent to which risk treatment methods are used (5 variables - elimination of risky activity, outsourcing of risky activity, application of risk mitigation measures, passive acceptance of risks, active acceptance of risks) has a high value (0.566) and in the same direction. In addition, the results of the regression analysis for the selected SMEs, described in Table 6, show that R Square has a value of 0.321 , indicating that the model is able to explain approximately $32.1 \%$ of the variability of integrating risk management into current activities. Romanian SMEs. This means that approximately $67.9 \%$ of the variations in the integration of risk management in the current activities of the sampled SMEs are determined by other factors that are not included in the model. This result is corroborated by the Adjusted R Square of about 0.299, which is, in fact, the proportion of total variation explained by the model. 
Table 6. Multiple correlation between risk treatment methods and dependent variable

\begin{tabular}{|c|c|c|c|c|c|c|c|}
\hline \multirow{2}{*}{ Model } & R & $\begin{array}{c}\text { R } \\
\text { Square }\end{array}$ & $\begin{array}{c}\text { Adjuste } \\
\text { d R } \\
\text { Square }\end{array}$ & $\begin{array}{c}\text { Std. } \\
\text { Error } \\
\text { of the } \\
\text { Estimate }\end{array}$ & \multicolumn{3}{|c|}{ Change Statistics } \\
\cline { 4 - 8 } & R Square & $\begin{array}{c}\text { F } \\
\text { Change }\end{array}$ & $\begin{array}{c}\text { Sig. F } \\
\text { Change }\end{array}$ \\
Change \\
\hline $\begin{array}{c}\text { Risk treatment } \\
\text { methods }\end{array}$ & $0.566^{\mathrm{a}}$ & 0.321 & 0.299 & 1.008 & 0.321 & 14.927 & 0.001 \\
\hline
\end{tabular}

Source: Own calculations

Similarly, the results of the F-Statistics test, as reflected in Table 6, show a p value of less than 0.01 , this clearly suggests that simultaneously the explanatory variables (elimination of risky activity, outsourcing of risky activity, application of risk mitigation measures, passive acceptance of risks, active acceptance of risks) are significantly associated with the dependent variable, integrating risk management into current activities.

In Table 7, the results of the linear regression analysis show that the risk treatment methods that influence the extent to which risk management is included in the current activities of SMEs, at the level of statistical significance of 0.01 , are represented by the outsourcing of risky activities (t-statistics $=4.083 ; p$-value $<0.001$ ) and application of risk mitigation measures (t-statistics $=3.586 ; p$-value $<0.001$ ).

The outsourcing of risky activities and the application of various risk mitigation methods have the highest beta coefficients $(0.379 ; 0.332)$, indicating that they have the greatest influence on predicting the degree of integration of risk management in the current activities of Romanian SMEs. The association between the outsourcing of risky activity and the application of risk mitigation methods and the integration of risk management into current activities is significant and positive, meaning that the greater the extent to which these two risk treatment methods are used, the greater the degree to which management risk is integrated into the current activities of the SMEs surveyed.

Table 7. Multiple regression between risk treatment methods and dependent variable

\begin{tabular}{|c|c|c|c|c|c|c|c|c|}
\hline & \multirow{2}{*}{ Model } & \multicolumn{2}{|c|}{$\begin{array}{l}\text { Unstandardized } \\
\text { Coefficients }\end{array}$} & \multirow{2}{*}{$\begin{array}{c}\text { Standardized } \\
\text { Coefficients } \\
\text { Beta }\end{array}$} & & \multirow{2}{*}{ Sig. } & \multicolumn{2}{|c|}{$\begin{array}{l}\text { Collinearity } \\
\text { Statistics }\end{array}$} \\
\hline & & B & $\begin{array}{l}\text { Std. } \\
\text { Error }\end{array}$ & & & & Tolerance & VIF \\
\hline \multirow{6}{*}{1} & (Constant) & 1.315 & 0.286 & & 4.595 & 0.000 & & \\
\hline & $\begin{array}{c}\text { Elimination of risky } \\
\text { activity }\end{array}$ & -0.071 & 0.090 & -0.074 & -0.794 & 0.429 & 0.499 & 2.003 \\
\hline & $\begin{array}{c}\text { Outsourcing of risky } \\
\text { activity }\end{array}$ & 0.369 & 0.090 & 0.379 & 4.083 & 0.000 & 0.498 & 2.009 \\
\hline & $\begin{array}{l}\text { Application of risk } \\
\text { mitigation measures }\end{array}$ & 0.328 & 0.091 & 0.332 & 3.586 & 0.000 & 0.501 & 1.998 \\
\hline & $\begin{array}{l}\text { Passive acceptance of } \\
\text { risks }\end{array}$ & -0.010 & 0.089 & -0.009 & -0.109 & 0.914 & 0.684 & 1.461 \\
\hline & $\begin{array}{c}\text { Active acceptance } \\
\text { of risks }\end{array}$ & 0.024 & 0.101 & 0.023 & 0.236 & 0.814 & 0.436 & 2.292 \\
\hline
\end{tabular}

Source: Own calculations

Table 8 shows the results of the above analysis, indicating acceptance or rejection of the hypothesis. 
Table 8. The results of hyphothesis testing

\begin{tabular}{|c|c|c|c|}
\hline Hypothesis & F-statistics & $\boldsymbol{p}$ & \begin{tabular}{c} 
Acceptation of the null hypothesis \\
\hline H1
\end{tabular} \\
\hline H2 & 28.606 & 0.001 & NO (there is a connection between the analysed variables) \\
\hline H3 & 7.52 & 0.001 & NO (there is a connection between the analysed variables) \\
\hline H4 & 10.983 & 0.001 & NO (there is a connection between the analysed variables) \\
\hline H5 & 46.109 & 0.001 & NO (there is a connection between the analysed variables) \\
\hline H6 & 14.927 & 0.004 & NO (there is a connection between the analysed variables) \\
\hline & NO (there is a connection between the analysed variables) \\
\hline
\end{tabular}

\section{CONCLUSIONS}

The purpose of this article is to explore the organizational factors and risk management practices that affect the extent to which risk management is integrated into the current activities of Romanian SMEs. In order to achieve this goal, the research based on the questionnaire addressed to Romanian SMEs provided results that have a major contribution to determining the stage of implementing risk management within this category of organizations. The results show that organizational differences affect the extent to which risk management is integrated into the current activities of SMEs. Thus, medium-sized enterprises, which operate globally and have a medium market presence (5-10 years) have a major influence on the measure of integrating risk management into current activities, due to the existence of considerable financial resources and human resources capabilities, well-organized procedures, subject to continuous adaptation to the requirements of global collaborators and regulatory requirements in terms of risk management, and greater experience than organizations up to 5 years old, and a reluctance lower than companies with experience up to 25 years.

The results also show that there is a positive relationship between the risk management practices in SMEs and the inclusion of information related to risk management in current activities., thus the correlation coefficient for risk identification techniques is $0.605,0.603$ for risk assessment analyses and 0.566 for risk treatment methods.

The use of questionnaires, as a risk identification technique, has a negative influence on the extent to which risk management is integrated into the current activities of Romanian SMEs. Instead, the quantitative risk assessment analysis, and the risk treatment methods represented by the application of risk mitigation measures and risk outsourcing have a positive influence on the integration of risk management in the current activities of Romanian SMEs.

\section{ACKNOWLEDGEMENT}

This study was conducted through the post-doctoral advanced research studies for the academic years 2018-2020, 2019-2021 and doctoral studies 2017-2020, Management field, coordinator Bucharest University of Economic Studies.

\section{REFERENCES}

Adeyemi, S. B. \& Fagbemi, T. O. (2010). Audit Quality, Corporate Governance and Firm Characteristics in Nigeria. International Journal of Business and Management, 5(5), 169-179.

AIRMIC, ALARM \& IRM. (2010). A Structured Approach to Enterprise Risk Management (ERM) and the Requirements of ISO 31000. Retrieved March 12, 2020, from https://www.theirm.org/media/886062/ISO3100_doc.pdf. 
Alquier, A. B. \& Tignol, M. L. (2006). Risk Management in Small and Medium-Sized Enterprises. Production Planning and Control, 17(3), 273-282.

Aven, T. (2012). The Risk Concept - Historical and Recent Development Trends. Reliability Engineering \& System Safety, 99, 33-44.

Broadleaf Capital International. (2012). A Simple Guide to Risk and Its Management. Pymble, New South Wales, Australia. Retrieved March 22, 2020, from http://broadleaf.com.au/old/pdfs/trng_tuts/Tut_Simple_Guide_to_Risk_v11.pdf.

Brustbauer, J. (2016). Enterprise Risk Management in SMEs: Towards a structural model. International Small Business Journal, 34(1), 70-85.

Buehler, K., Freeman, A. \& Hulme, R. (2008, September). The Risk Revolution. McKinsey Working papers on Risk, 1, 1-40.

CPA Australia. (2009). Risk Management Guide for Small to Medium Businesses. Retrieved March 22, 2020, from https://www.cpaaustralia.com.au/ /media/corporate/ allfiles/document/professional-resources/business/risk-management-guide-for-small-tomedium-businesses.pdf.

Crovini, C. (2019). Risk Management in Small and Medium Enterprises (1st Edition ed.). London: Routledge.

Djapic, M., Lukic, L. \& Popovic, P. (2013). Technical Product Risk Assessment Integration into the Enterprise Risk. Technical Gazette 20(4), 721-730.

European Commission. (2018, November). Annual Report on European SMEs 2017/2018: SMEs growing beyond borders. Retrieved February 17, 2020, from https://ec.europa.eu/docsroom/documents/32601/attachments/1/translations/en/renditions/ native.

European Commission. (2018). 2017 SBA Fact Sheet-Romania. Retrieved March 8 2020, from https:/ec.europa.eu/docsroom/documents/29489/attachments/24/translations/en/ renditions/pdf.

Falkner, E. M. \& Hiebl, M. R. (2015). Risk Management in SMEs: a Systematic Review of Available Evidence. The Journal of Risk Finance, 16(2), 122-144.

Frigo, M. L. \& Anderson, R. J. (2011). Strategic Risk Management: A foundation for improving enterprise risk management and governance. Journal of Corporate Accounting \& Finance, 22(3), 81-88.

Global Association of Risk Professionals. (2007). Foundations of Risk Management. Jersey City, New Jersey, USA. Retrieved January 5, 2020, from http://www.gocharter. com.tw/download/20110810FRM_Risk_mgn_Basis\%20_new-sample.pdf.

Grace-Martin, K. (2008, Octomber). Can Likert Scale Data Ever Be Continuous? Article Alley. Retrieved March 6, 2020, from The Analysis Factor: https://www.theanalysisfactor.com/can-likert-scale-data-ever-be-continuous/.

Henschel, T. (2008). Risk Management Practices of SMEs: Evaluating and Implementing Effective Risk Management Systems. Berlin: Erich Schmidt Verlag.

Hillson, D. (2002). Extenting the Risk Process to Manage Opportunities. International Journal of Project Management, 20(3), 235-240. 
IMA. (2011). Enterprise Risk Management: Frameworks, Elements, and Integration. Montvale: Institute of Management Accountants. Retrieved December 17, 2019, from http://www.stjohns.edu/sites/default/files/documents/academics/tobin/enterprise_risk_ma nagement_frameworks.pdf.

ISO 31000:2009. (2009). Risk management - Principles and guidelines. International Organization for Standardization.

ISO Guide 73. (2009). Risk Management Terminology. Geneva, Switzerland: International Organization for Standardization (ISO).

Janney, J. J. \& Dess, G. G. (2006). The Risk Concept for Entrepreneurs Reconsidered: New Challenges to the Conventional Wisdom. Journal of Business Venturing, 21(3), 385-400.

Jayathilake, P. M. (2012). Risk Management Practices in Small and Medium Enterprises: Evidence from Sri Lanka. International Journal of Multidisciplinary Research, 2(7), 226-234.

Karadag, H. (2016). The Role of SME's and Entrepreneurship on Economic Growth in Emerging Economies within the Post-Crisis Era: an Analysis from Turkey. Journal of Small Business and Entrepreneurship Development, 4(1), 22-31.

Kelliher, P. O., Wilmot, D., Vij, J. \& Klumpes, P. J. (2011, Octomber). A Common Risk Classification System for the Actuarial Profession. A Discussion Paper. London: The Institute and Faculty of Actuaries. Retrieved December 12, 2019, from https://www.actuaries.org.uk/documents/common-risk-classification-system-actuarialprofession.

Keskin, H., Senturk, C., Sungur, O. \& Kiris, H. M. (2010). The Importance of SMEs in Developing Economies. 2nd International Symposium on Sustainable Development, (ISSD 2010), June 8-9 (pp. 183-192). Sarajevo: International Burch University.

Louw, A. \& Com, B. (2007). The Development of an Enterprise-Wide Risk Management Framework in an Organisation - Mini-dissertation.

Muhammad, M. Z., Char, A. K., Yasoa, M. R. \& Hassan, Z. (2010). Small and Medium Enterprises (SMEs) Competing in the Global Business Environment: A Case of Malaysia. International Business Research, 3(1), 66-75.

Myers, R. (1990). Classical and Modern Regression with Applications (2nd ed.). Boston: Duxbury Press.

Nieuwenhuizen, C. (2007). Business Management for Entrepreneurs. Cape Town: Juta.

Norman, G. (2010). Likert Scales, Levels of Measurement and the "Laws". Advances in Health Sciences Education 15(5), 625-632.

OECD. (2017, June). Enhancing the Contributions of SMEs in a Global and Digitalised Economy. Retrieved February 20, 2020, from https://www.oecd.org/mcm/documents/ C-MIN-2017-8-EN.pdf.

Popa, D., Miricescu, D. \& Faloba, V. (2015). Gestionarea Riscurilor în cadrul IMM-rilor: Tehnică Managerială de bază în Implementarea proiectelor. Review of Management \& Economic Engineering, 14(3), 581-592.

Prioteasa, A. L. \& Ștefan, V. E. (2019). A Perspective of Risk Management in Romanian SMEs. 33rd International Business Information Management Association Conference (pp. 8667-8681). Granada: IBIMA Publishing. 
Project Management Institute. (2008). A Guide to the Project Management Body of Knowledge (PMBOK® Guide) 4th ed. Newtown Square: PMI.

Raz, T. \& Hillson, D. (2005). A Comparative Review of Risk Management Standards. Risk Management: An International Journal, 7(4), 53-66.

Rostami, A., Sommerville, J., Wong, I. L. \& Lee, C. (2015). Risk Management Implementation in Small and Medium Enterprises in the UK Construction Industry. Engineering, Construction and Architectural Management, 22(1), 91-107.

Savlovschi, L. I. \& Robu, N. R. (2011). The Role of SMEs in Modern Economy. Economia. Seria Management, 14(1), 277-281.

Sobel, P. J. \& Reding, K. F. (2004). Aligning Corporate Governance with Enterprise Risk Management. Management Accounting Quarterly 5(2), 29-37.

Standards Australia/ Standards New Zeeland. (2004). AS/NZ 4360:2004 Risk management. Sydney.

The Institutes. (n.d). Introduction to Risk Management. Retrieved January 23, 2020, from https://www.theinstitutes.org/doc/resources/ARM_54.pdf.

Verbano, C. \& Venturini, K. (2013). Managing Risks in SMEs: A Literature Review and Research Agenda. Journal of Technology Management \& Innovation, 8(3), 186-197.

Watt, J. (2007). Strategic Risk Management for Small Businesses. In J. Reuvid, Managing Business Risk 2 nd Edition - a practical guide to protecting your business (pp. 31-40). London: Kogan Page. 